\title{
Remnants of Mesoarchaean oceanic crust in the Tartoq Group, South-West Greenland
}

\author{
Kristoffer Szilas, Vincent J. van Hinsberg, Alexander F. M. Kisters, Thomas F. Kokfelt, \\ Anders Scherstén and Brian F. Windley
}

The Tartoq Group is located in the Sermiligaarsuk fjord region in South-West Greenland in an area of approximately $20 \times 50 \mathrm{~km}$ (Fig. 1). The Tartoq Group consists of several discrete, fault-bound blocks of metavolcanic rocks, surrounded by Archaean tonalite-trondhjemite-granodioritetype (TTG) gneisses. A zircon age of $2996.3 \pm 5.9 \mathrm{Ma}$ of a TTG intrusion provides a minimum age for the formation of the Tartoq Group (Fig. 2). The metavolcanic rocks probably show the lowest degree of metamorphism found anywhere in the Archaean craton of Greenland. Here we present a new model for the origin of the metavolcanic rocks of the Tartoq Group based on geochemical, metamorphic and structural data. The samples used for this study were collected by the Geological Survey of Denmark and Greenland (GEUS) in 2009 and 2010. The study is part of a joint project between the Greenland Bureau of Minerals and Petroleum and GEUS on the mineral potential of south-western Greenland.

\section{Geology of the Tartoq Group}

The Tartoq Group can be divided into five main lithological units: (1) subaqueous, mafic pillow lavas, (2) mafic dykes and sills with semi-ophitic textures, (3) gabbros with relict magmatic textures and tonalite-trondhjemite-granodiorite composition, (4) ultramafic rocks that are mainly serpen- tinites and (5) felsic schists that commonly show high strain with mylonitic textures. In addition, a marble unit occurs in the Nuuluk block; gneiss of quartz dioritic composition lies in a large breccia zone with intrusive tonalite-trondhjemitegranodiorite-type (TTG) gneisses that have been fractured and chloritised; and undifferentiated pegmatites are found in the Bikuben and the Iterlak blocks. The lithologies and their relations were described by Higgins (1968), Berthelsen \& Henriksen (1975), Petersen (1992) and van Hinsberg et al. (2010).

Greenschist facies rocks with pseudo-sections indicating peak metamorphic conditions of $380^{\circ} \mathrm{C}$ at $2 \mathrm{kbar}$ dominate the Nuuluk block in the west (Fig. 1). The metamorphic grade increases to upper amphibolite facies with pressure and temperature calculated to $650^{\circ} \mathrm{C}$ at $6-7 \mathrm{kbar}$ in the Bikuben block in the east. Evidence for partial melting is seen for at least one locality in the Bikuben block, where leucosomes occur in fold hinges of amphibolites. Peak metamorphic assemblages generally correlate with the different lithological units, which means that pillow lavas and shallow dykes or sills are at a lower grade and gabbro and serpentinite units at a higher grade (van Hinsberg et al. 2010).

The Tartoq Group is thrust (top to the SE) and imbricated with younger TTG gneisses. Kilometre-scale nappes, low-angle shear zones, and younger cataclastites formed as a
Fig. 1. Simplified geological map of the Sermiligaarsuk fjord area, with the names of seven blocks with supracrustal rocks belonging to the Tartoq Group. The undifferentiated orthogneiss surrounding TGG gneisses has ages ranging from about $2500 \mathrm{Ma}$ to $3000 \mathrm{Ma}$. The Ketilidian supracrustals overly the Tartoq Group unconformably (van Hinsberg et al. (2010). The Tartoq Group is mostly in tectonic contact with the surrounding orthogneiss, but a few intrusive relations are preserved at south Iterlak and north Amitsuarsua blocks. The supracrustal blocks form thrust sheets and lateral ramps with internal top to the SE kinematic indicators.

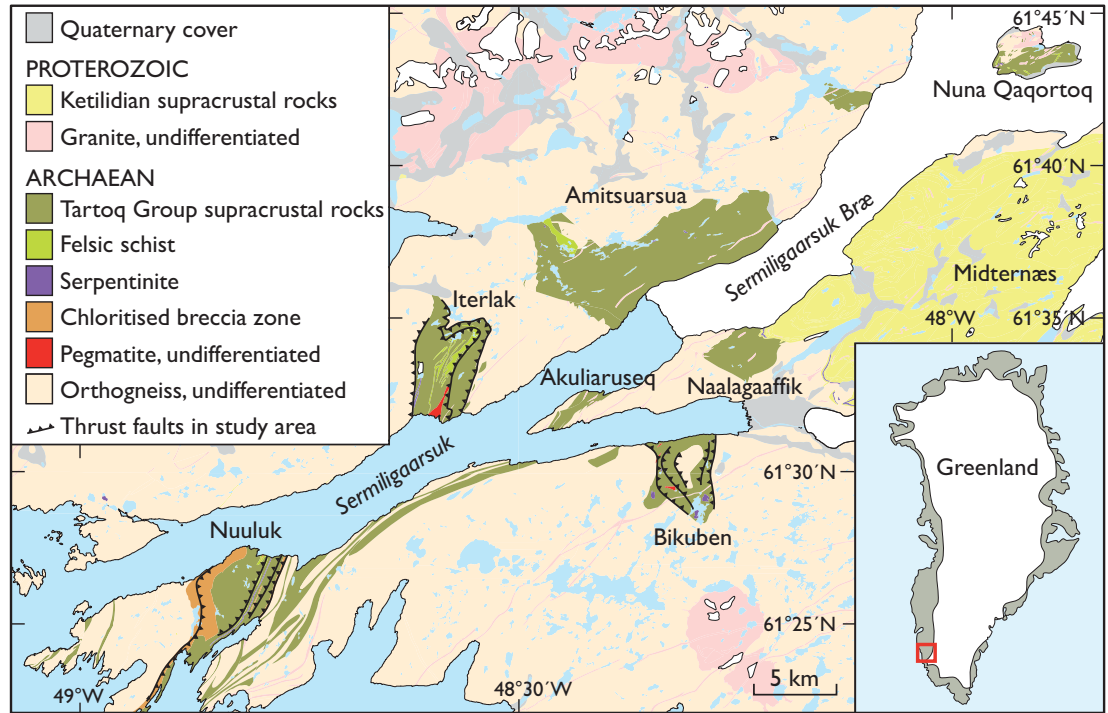


result of the accretion and progressive exhumation of these rocks. Deformation was associated with hydrothermal alteration (with Au mineralisation at $c .450^{\circ} \mathrm{C}$ ) that overprinted regional metamorphic parageneses and intense carbonation in high strain zones.

Felsic, 1-80 $\mathrm{m}$ thick schist bodies in the mafic sequence represent high-strain zones where TTG gneisses have been preferentially sheared in the metavolcanic rocks. Some of these mylonitic, felsic schists gave zircon ages of $c .2800 \mathrm{Ma}$ to $3700 \mathrm{Ma}$ which indicate the subsurface presence of old crustal material. These ages also suggest that the felsic schists are not part of the Tartoq Group, but are tectonic in origin.

\section{Geochemistry}

The geochemical data were screened and samples showing evidence of post-magmatic alteration were rejected. Microscopy of thin sections was used to identify the least altered samples. Samples with quartz and carbonate veining and samples showing excessive large-ion lithophile elements (LILE) enrichment were discarded. Pillow lavas are prone to sea-floor alteration during extrusion, and therefore this group of rocks may be under-represented in the screened dataset.

The Tartoq Group metavolcanic rocks (pillow lavas, dykes or sills and gabbro units) all have tholeiitic basaltic compositions. Trace-element variations within the volcanic sequence broadly show that the incompatible trace elements increase with decreasing $\mathrm{MgO}$ content and the compatible trace elements decrease with falling $\mathrm{MgO}$, consistent with trends of fractional crystallisation of olivine, clinopyroxene and perhaps plagioclase. The major elements show trends similar to what would be expected for a tholeiitic fractionation series. The scatter seen within the data may be due to metamorphic or slight hydrothermal background alteration. The metavolcanic rocks generally have flat, primitive, mantle-normalised trace-element patterns with $\mathrm{La}_{\mathrm{N}} / \mathrm{Sm}_{\mathrm{N}}=$ $0.8-1.0$, but they show negative $\mathrm{Nb}$ anomalies with $\mathrm{Nb}_{\mathrm{N}} /$ $\mathrm{La}_{\mathrm{N}}=0.4-0.9$ (Fig. 3). In tectonic discrimination diagrams, which rely on immobile trace elements, the metavolcanic rocks plot in the mid-ocean ridge basalt (MORB) or islandarc tholeiite (IAT) fields. La, $\mathrm{Y}$ and $\mathrm{Nb}$ abundances are similar to those of some modern back-arc basalts (BAB).

The serpentinites have median values of $\mathrm{SiO}_{2}(45 \mathrm{wt} \%)$, $\mathrm{MgO}$ (37 wt\%), $\mathrm{FeO}_{\mathrm{T}}$ (14.5 wt\%), $\mathrm{Cr}$ (3100 ppm), Ni (600 ppm) and essentially no $\mathrm{CaO}$ or $\mathrm{Al}_{2} \mathrm{O}_{3}$, combined with a large negative chondrite-normalised Eu anomaly (Fig. 3). The serpentinites mainly consist of normative olivine and hypersthene (3:1 ratio) and are thus harzburgitic in composition.

The felsic schist units show complete overlap in major and trace elements with the surrounding gneisses. This is consistent with the structural interpretation that they are deformed rocks along thrust faults, and hence unrelated to the volcanic sequence.

\section{Discussion}

The metavolcanic rocks in the Tartoq Group have similar trace-element patterns, with pronounced negative $\mathrm{Nb}$ anomalies (Fig. 3). Their overall major and trace-element variations are consistent with fractional crystallisation processes. These features suggest that the metavolcanic rocks are co-magmatic. The dykes and sills have the highest concentration of incompatible trace elements. This is consistent with the fact that they have the lowest $\mathrm{MgO}$ content and they thus form the more evolved portion of the magma pile. The four pillow lavas show a narrow compositional range that

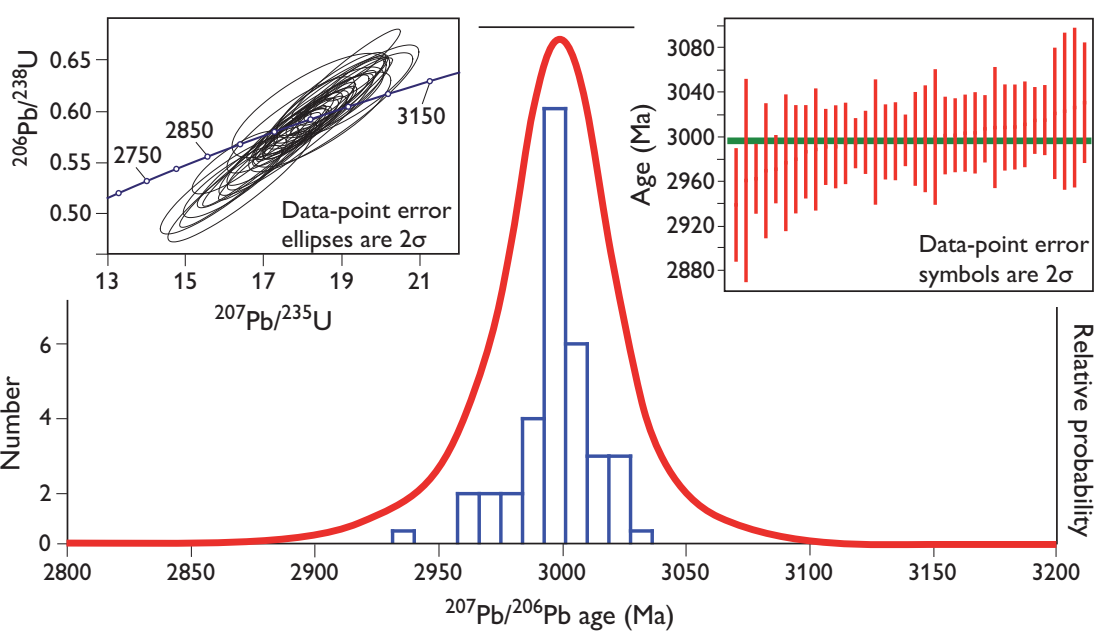

Fig. 2. Zircon U/Pb age of sample GGU 510771 using laser ablation inductively coupled mass spectrometry. The sample is an intrusive orthogneiss from the northern contact in the Amitsuarsua block and the age was $2996.3 \pm 5.9 \mathrm{Ma}$ ( $95 \%$ confidence interval). The zircons in the sample are prismatic and show oscillatory growth zonation. Only the zircon cores were analysed. Spots that are concordant within $\pm 10 \%$ have been used and they form a tight normal distribution with a mean square weighted deviation of 0.76 and a probability of 0.85 . The mean was weighted by data point errors only (no points were rejected). The analyses cut the concordia with minimal signs of lead loss and thus provide a robust age. 
Fig. 3. Spidergrams showing primitive mantlenormalised trace-element compositions of samples from the Tartoq Group (normalisation after Sun \& McDonough 1989). Only the relatively immobile trace elements are shown due to the likely mobility of the large ion lithophile elements during metamorphism and seafloor alteration. The pillow lavas, dykes and sills form fairly well-constrained compositional groups. In contrast, the gabbros show greater compositional variation, reflecting variable effects of fractionation and accumulation processes. The serpentinites show low concentrations and a large negative Eu anomaly, which imply melt or mineral equilibrium processes involving plagioclase. The yellow areas shown in the spidergrams represent the total data field of the Tartoq Group.
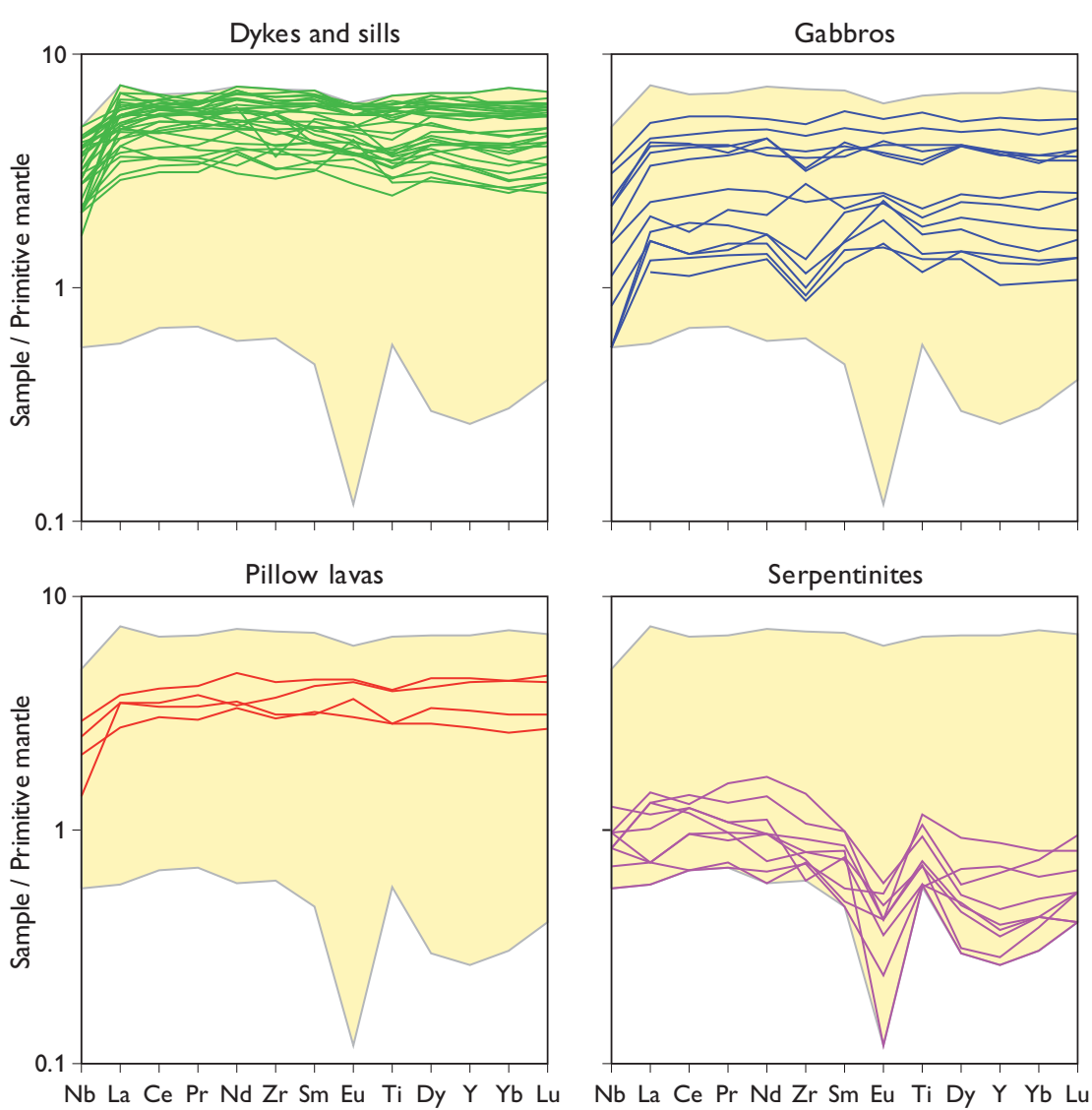

overlaps with the dykes and sills, as to be expected if the latter represent the feeding channels of lava flows. A broader compositional range is observed for the gabbros. Positive Eu anomalies, low trace element concentrations combined with high contents of $\mathrm{CaO}, \mathrm{Al}_{2} \mathrm{O}_{3}$ and $\mathrm{Sr}$ suggest some accumulation of plagioclase.

The serpentinites show low incompatible trace-element concentrations, major element contents and normative compositions. These features are consistent with harzburgite that could represent either cumulates of the volcanic sequence or the residual source mantle. PGE patterns show depletion in $\mathrm{Pt}$ and $\mathrm{Pd}$ which is also observed in peridotite xenoliths from kimberlites in the area (Wittig et al. 2010). The serpentinites probably represent a sub-continental lithospheric mantle, which experienced high degrees of melt extraction and was exhumed together with the supracrustal rocks of the Tartoq Group.

No co-genetic, calc-alkaline rocks have been found in the Tartoq volcanic sequence and it is therefore unlikely that the volcanic rocks erupted through continental crust or formed in a mature arc setting. At first glance the geochemical features of the metavolcanic rocks resemble those of the modern MORB, but they differ distinctly by having a negative $\mathrm{Nb}$ anomaly and by their pattern of undepleted light rare-earth elements. The tectonic discrimination diagrams point to a IAT setting, but the lack of co-genetic, calc-alkaline rocks argues against this. The $\mathrm{La}, \mathrm{Y}$ and $\mathrm{Nb}$ concentrations indicate a BAB setting, which is in agreement with the arc 'flavour' that is suggested by the IAT affinity.

The major and trace-element values for the Tartoq Group are similar to data from Archaean tholeiitic rocks from the Superior Province of Canada, which formed in a BAB setting according to the interpretation of Sandeman et al. (2006). Another explanation for Archaean tholeiites is that they formed in an oceanic plateau setting similar to the recent Ontong Java plateau (Arndt et al. 1997). All examples of Archaean tholeiites are associated with abundant komatiites. However, komatiites are rare in the supracrustal belts of Greenland and absent in the Tartoq Group, which argues against an oceanic plateau setting. Rocks from a BAB setting are also more likely to be preserved over time, because the crust in $\mathrm{BAB}$ settings is thin and located in a collision setting, like the present-day Lau and Mariana back-arc crust (Martinez \& Taylor 2003).

It is mainly the higher degree of partial melting estimated for Archaean tholeiites compared to present day MORB settings that have led some authors to argue for an oceanic plateau setting, whereas the LILE enrichment and negative 
$\mathrm{Nb}$ anomaly have led others to suggest a $\mathrm{BAB}$ environment. However, Rollinson (2010) suggested that the differences between modern MORB and Archaean non-arc tholeiites simply reflect high temperatures of the Archaean mantle. Rollinson's model provides a robust explanation for the geochemical features of the Tartoq Group. The Tartoq Group may be a product of a hotter mantle giving rise to a thicker melting column, which affected the composition and differentiation of MORB magmas and resulted in the observed discrepancies compared with the modern MORB.

Regardless of the precise setting of ocean crust formation, the similar flat trace-element patterns and fractional crystallisation trends of all the metavolcanic rocks of the Tartoq Group, together with the presence of serpentinites, indicate that the rocks form a co-magmatic assemblage resembling an ophiolitic ocean floor sequence. Two possible scenarios can explain the metamorphic and structural observations: (1) shallow subduction followed by TTG formation due to slab melting made the oceanic crust sufficiently buoyant to cause exhumation in a subduction channel and subsequent incorporation into the overriding plate; (2) the Tartoq Group formed from the overriding plate in an oceanic flake-style subduction setting that was dragged down with a shallow $P T$-trajectory by the subducting plate and later rebounded during aborted subduction (or slab break-off?), which could initiate TTG formation by decompression melting of the lower crust. In both scenarios we envisage that subduction took place in an intra-oceanic setting, resulting in the lack of continent-derived material in the Tartoq Group. Both tectonic environments could give rise to the observed peak metamorphic assemblages and later retrogression by fluid input together with inter-thrusting with the TTG gneisses, which resulted in the tectonic slices and slabs that we see today.

\section{Conclusions}

Based on geochemical, metamorphic and structural data we have developed a new model according to which the Tartoq Group is a slab of oceanic crust. We interpret the protolith of the Tartoq Group as a structurally dismembered section of Archaean oceanic crust of either MORB or BAB affinity, which might provide valuable insight into Archaean geodynamics.

\section{References}

Arndt, N.T., Kerr, A.C. \& Tarney, J. 1997: Dynamic melting in plume heads: the formation of Gorgona komatiites and basalts. Earth and Planetary Science Letters 146, 289-301.

Berthelsen, A. \& Henriksen, N. 1975: Geological map of Greenland, 1:100 000, Ivigtut 61 V.1 Syd. Descriptive text, 169 pp. Copenhagen: Geological Survey of Greenland.

Higgins, A.K. 1968: The Tartoq Group on Nuna qaqortoq and in the Iterdlak area, South-West Greenland. Rapport Grønlands Geologiske Undersøgelse 17, 17 pp.

Martinez, F. \& Taylor, B. 2003: Controls on back-arc crustal accretion: insights from the Lau, Manus and Mariana basins. In: Larter, R.D. \& Leat, P.T. (eds): Intra-oceanic subduction systems: tectonic and magmatic processes. Geological Society Special Publications (London) 219, $19-54$.

Petersen, J.S. 1992: Nuuluk-Iterlak gold and massive-sulfide project, Taartoq Archaean greenstone belt, SW Greenland, 164 pp. Unpublished field report, Nunaoil A/S.

Rollinson, H. 2010: Coupled evolution of Archean continental crust and subcontinental lithospheric mantle. Geology 38, 1083-1086.

Sandeman, H.A., Hanmer, S., Tella, S., Armitage, A.A., Davis, W.J. \& Ryan, J.J. 2006: Petrogenesis of Neoarchaean volcanic rocks of the MacQuoid supracrustal belt: a back-arc setting for the northwestern Hearne subdomain, western Churchill Province, Canada. Precambrian Research 144, 140-165.

Sun, S. \& McDonough, W. F. 1989: Chemical and isotopic systematics of oceanic basalts: implications for mantle composition and processes. In: Saunders, A.D. \& Norry, M.J. (eds): Magmatism in the ocean basins. Geological Society Special Publications (London) 42, 313-345.

van Hinsberg, V.J., Szilas, K. \& Kisters, A.F.M. 2010: The Tartoq Group, SW Greenland: mineralogy, textures and a preliminary metamorphic to hydrothermal history. Danmarks og Grønlands Geologiske Undersøgelse Rapport 2010/120, 40 pp.

Wittig, N., Webb, M., Pearson, D.G., Dale, C.W., Ottley, C.J., Hutchinson, M., Jensen, S.M. \& Luguet, A. 2010: Formation of the North Atlantic Craton: Timing and mechanisms constrained from Re-Os isotope and PGE data of peridotite xenoliths from S.W. Greenland. Chemical Geology 276, 166-187.

\footnotetext{
Authors' addresses

K.S. \& T.F.K., Geological Survey of Denmark and Greenland, Øster Voldgade 10, 1350 Copenhagen K, Denmark. E-mail: ksz@geus.dk

V.J.H., Department of Earth Sciences, University of Oxford, South Parks Road, Oxford OX1 3AN, UK.

A.F.M.K., Department of Earth Sciences, Stellenbosch University, Matieland 7602, South Africa.

A.S., Deptartment of Earth and Ecosystem Sciences Division of Geology, Lund University Sölvegatan 12, 22362 Lund, Sweden.

B.F.W., Department of Geology, University of Leicester, University Road, Leicester, LE1 7RH, UK.
} 